YAK 347.4

DOI https://doi.org/10.32837/chc.v0i41.415

Гуйван Петро Амитрович,

канАиАат юриАичних наук, заслужений юрист України, професор

Полтавського інституту бізнесу

ORCID ID: 0000-0003-3058-4767

\title{
ПРАВОВЕ СПІВВІДНОШЕННЯ СТРОКІВ ЗДІЙСНЕННЯ РЕГУЛЯТИВНОГО Й ОХОРОННОГО ЦИВІЛЬНОГО ПРАВА
}

Постановка проблеми. 3 огляду на значну різноманітність сучасних цивільних правовідносин із позиції їх формування, обсягів повноважень управленого суб'єкта, способу реалізації тощо як загальна необхідність виглядає існування різних за юридичною природою строків Аля реалізації суб'єктивного матеріального права. Нині в нашій цивілістичній науці та правозастосовній практиці продовжуються Аискусії стосовно віАнесення різних конкретних строків, що визначають тривалість окремих повноважень чи обов'язків особи, до тих чи інших виАів. Тому питання визначення правової сутності того чи іншого цивільного строку проАовжує залишатися актуальним. На наш погляА, визначальним моментом, який впливає на диференціацію цивільних строків, $€$ знаходження матеріальних віАносин у регулятивному або в охоронному стані.

Мета статті полягає в розгляАі питання про порівняння строків зАійснення регулятивного цивільного права та строків реалізації права на захист у разі правопорушення.

Виклад основного матеріалу дослідження 3 повним обґрунтуванням отриманих наукових результатів. Регулятивне цивільно-правове правовіАношення складається та реалізується за умови належного зАійснення свого права управненою особою та віАповіАного належного виконання свого обов'язку зобов'язаною особою. Право кредитора, що випливає з такого регулятивного зобов'язання, не наАілене властивістю примусової реалізації, оскільки воно не супровоАжується так званими приводами Ао позову [1, с. 215-219], зокрема не порушене іншими особами. Коли ж відбувається порушення цивіль- ного права, воно набуває зАатності бути захищеним, і такий захист не може охоплюватися механізмами, притаманними правовому регулюванню регулятивних взаємин, навіть 3 урахуванням трансформацій суб'єктивного права. Такої позиції посліАовно Аотримуються ряА знаних українських цивілістів. НаприклаА, Н.С. Кузнєцова, визначаючи самостійність захисного права особи, порівнює його з іншими суб'єктивними правами, котрі можуть зАійснюватися носіями на свій розсуА на засадах Аиспозитивності та вільного волевиявлення, позаяк Аля права на захист законодавцем встановлено загальний Аля цивільних прав режим правового регулювання [2, с. 30].

У публіцистичній мітературі питання часової визначеності піА час здійснення взаємодій регулятивного й охоронного поряАКу АосліАжувалися такими вченими, як А.І. Мейєр, В.П. Грибанов, В.В. Ауць, В.В. БутнєВ, П.Ф. Єлісєйкін, С.О. Сліпченко. Ними здійснено аналіз темпоральної склаАової частини права особи на вчинення власних продуктивних Аій і вимагання необхідної поведінки віА контрагента як піА час належного виконання, так і після правопорушення. ОАнак окремі взаємодії, особливо у площині практичної реалізації суб'єктивних повноважень носія права у часі, залишаються вивченими недостатньо. Тож виникає багато суперечок і різнобачень, зокрема щодо з'ясування темпоральної межі, коли припиняється регулятивний стан матеріальних віАносин і виникає право на захист, у т. ч. шляхом преА'явлення позовного Аомагання і здійснення права на примус за Аопомогою юрисАикційного органу - суду. ПреАметом цієї праці $€$ порівняльний аналіз Авох зовнішньо схожих, але Аостат- 
ньо різних за сутністю та призначенням матеріально-правових строків: присічних і Аавнісних (позовної Аавності). На базі детального аналізу юридичного змісту вказаних темпоральних явищ буде зАійснено виокремлення кожного з цих строків, що і становить мету дослідження.

У нашій роботі автор не полемізує із приводу визначення поняття преклюзивного (присічного) строку: воно викладене в інших працях [3, с. 183-213] і розуміється як встановлений період Аля вчинення повноважною особою односторонніх Аій фактичного поряАку, спрямованих на набуття, збереження чи зміну іншого суб'єктивного матеріального права. Керуючись такою Аефініцією, можемо сказати, що до обмежених присічними строками належать, наприклаА, право спаАкоємця на прийняття спаАщини віА Аня її відкриття, право відшукувати загублену річ, безАоглядну Аомашню тварину тощо [4, с. 94]. Іноді навіть у тих випадках, коли реалізація матеріального права відбувається шляхом звернення Ао суду, теж треба говорити про строки зАійснення не охоронного, а регулятивного повноваження. Так, після публікації у ЗМІ про порушення провадження про банкрутство кредитор має звернутися з вимогою Ао господарського суду протягом одного місяця. У цих випадках ідеться не про позовну Аавність, а про строкове матеріальне право, а період його реалізації має присічний характер.

У науковій цивілістичній мітературі прийнято вважати, що присічні строки за своєю юридичною сутністю найбільш наближені Ао позовної Аавності, аАже з їх спливом пов'язується припинення суб'єктивного права та можливості його судового захисту. Отже, більшість Аослідників традиційно вивчали присічні строки саме порівняно з позовною Аавністю. Більш того, науковці часто не вбачали серйозних віАмінностей між Аавнісними та преклюзивними строками, вважаючи їх Авома різновидами єАиного цивільно-правового інституту [5, с. 255-262]. В обох випадках можливість реалізації цивільного права пов'язана з активними ініціативними Аіями самого кредитора, які він має вчинити в установлених темпоральних межах. Після збігу такого строку реалізація права є неможливою, а саме суб'єктивне право припиняється. Якщо Аія права обмежена часом, відповідно обмежена строком і можливість вчинення кредитором вказаних Аій. Із закінченням існування права припиняється і кореспондуючий йому обов'язок боржника, тож невчинення Аій не Аає змоги управненому суб'єкту Аосягти мети цивільного правовіАношення - реалізації свого матеріального права.

ЗАавалося би, зміст суб'єктивного права носія, обмеженого позовною Аавністю та присічним строком, однаковий - правомочність на власні активні дії зі спливом встановленого періоду припиняється, але насправді це не так, їхня юридична природа відмінна. Не можна погодитися із тверАженням, що закінчення присічного строку одночасно погашає притаманну захисну властивість права. Погасити можна мише те право, що вже виникло, тобто повноваження, яке існує. Якщо ж протягом присічного строку матеріальне право, зАійснення якого полягає у вчиненні певних активних Аій, не було реалізоване, немає підстав говорити про його порушення. Після закінчення періоду Аії правовстановлюючого повноваження особи, що не було реалізоване самим носієм, право на захист не припиняється, воно просто не виникає. Отже, неправильно стверАжувати, ніби зі спливом строку Аії суб'єктивного права припиняється і право на його судовий захист. Охоронне правовіАношення не може припинитися, позаяк воно взагалі не виникало.

Аосить часто помилки у визначенні характеру правовідношення, котре перебуває у певному стані, спричинені неправильною оцінкою моменту, коли в окремих зобов'язаннях фактично віАбулося правопорушення, а отже, припинилися регулятивні взаємини та виникло охоронне правовідношення. Є.О. Крашенінніков, вважаючи, що вимога вклаАника Ао установи банку про видачу вкладу $€$ регулятивним правом, а охоронне повноваження такого самого змісту виникає мише в разі віАмови у встановлений строк виконати вказану вище вимогу [6, с. 52-53], чомусь зовсім по-іншому обґрунтовує відносини, котрі виникають при страхуванні. Він вказує, що охоронне повноваження (а отже, і строк Аавності) за вимогами Ао страховика починається віА часу настання страхового випаАку, постулюючи можмивість виникнення охоронної вимоги щодо страхової виплати не віА часу правопорушення, а віА певної нейтральної події (страхового випаАку), настання певної дати [7, с. 56-57].

На наш погляА, вказана теза $є$ помилковою, але її прихильники все ж вказують на таку можмивість і як найбільш наочний приклаА наводять охоронне правовідношення, Ао складу якого вхоАить вимога про виплату страхової суми, котре, на їх переконання, виникає віА моменту страхового випадку. Тож виникає питання: чи є вимога про сплату страхової суми охоронно-правовим 
повноваженням особи, а також чи може вона отримати вигляА позовного Аомагання? Після настання страхового випадку у страхувальника з'являється право вимоги віА страховика переАбаченого Аоговором чи законом розміру страхової виплати. Якщо припустити, що страхувальник не звертається з такою вимогою до контрагента протягом встановленого строку, то він налалі втрачає можливість Аля цього, але це не охоронне відношення, а класичний випадок регулятивного зобов'язання, котре виникло віА часу настання відкладальної умови та строк виконання якого визначається моментом вимоги уповноваженого (ст. 530 ЦКУ). ЄАиною особливістю є те, що право на звернення до страховика обмежене часом, визначеним у Аоговорі або нормативно.

Отже, страховий випадок призводить Ао виникнення регулятивного права, якому кореспондує регулятивний обов'язок зАійснити страхову виплату. І мише у разі невиконання вказаного обов'язку у встановлений Аоговором чи правилами страхування строк відбудеться порушення вказаного суб'єктивного права. Саме віА цього моменту у страхувальника виникає охоронне повноваження, що може бути примусово реалізованим через суА. Більше того, невиконання цього обов'язку страховиком породжує не одну, а декілька охоронно-правових вимог (котрі, звісно можуть шляхом реалізації домагань бути примусово реалізовані за допомогою юрисдикційного органу): так, страхувальник може вимагати сплати страхової суми, віАшкодування нанесених неналежним виконанням збитків тощо. ОчевиАно, що таких вимог охоронного змісту він аж ніяк не міг пред'явити контрагентові віАразу після настання страхового випадку. Отже, підставою Аля виникнення в особи охоронного права та права на позов є не настання страхової події, а порушення страховиком регулятивного суб'єктивного права страхувальника на отримання страхової виплати.

Тож можемо Аійти висновку про те, що страховий випадок не є обставиною, яка перешкоджає зАійсненню відповідного права на отримання страхувальником страхових коштів, а саме це право відразу не стає охоронним, як про це іноді вказується в літературі [8, с. 40-41]. Страховий випадок ^иш встановлює початок дії віАповіАного регулятивного права вимагати страхової виплати. Такому повноваженню кореспондує обов'язок страховика протягом визначеного строку виплатити гроші. ^ише у разі порушення цього обов'язку з'являється охоронне право вимоги, яке може мати вигляА матеріального права на позов або позовного Аомагання.

Подібні Аоктринальні колізії спостерігаються також при оцінці юридичного змісту віАносин, пов'язаних із темпоральними чинниками, що регулюють механізм прийняття спадщини. Якщо із сутністю строку на прийняття спаАщини все більшменш зрозуміло (це класичний присічний період, який обмежує тривалість секундарного права), то стосовно часових характеристик і самого змісту права на поновлення цього строку або надання Аодаткового часто виникають Аискусії. ЗгіАно із правилом ч. 2 ст. 1272 ЦКУ спаАкоємець, котрий пропустив строк Аля прийняття спаАщини, все ж може подати заяву про її прийняття за наявності письмової згоди інших спаАкоємців, які прийняли спадщину. Фактично у цій нормі йдеться про можливість так званого відновлення присічного строку. Інакше кажучи, особа набуває права на участь у новому матеріа^ьному правовіАношенні майнового характеру, не реалізувавши упродовж присічного строку свого секундарного права.

За великим рахунком, ситуація щодо їхнього відновлення не притаманна Аля правового регулювання преклюзивних строків, але вона, власне, і не заборонена законодавством, тож за спеціальним нормативним приписом таке запроваАження цього механізму сліА визнати цілком припустимим. Ао речі, можливість спеціального регулювання присічних строків шляхом їхнього зупинення, віАновлення тощо $є$ одним із чинників, що відрізняє ці темпоральні прояви віА позовної Аавності, позаяк Аля останньої подібні механізми є загальним правилом [9, с. 79-80]. Отже, як бачимо, згінно із приписом ч. 2 ст. 1272 віАбувається віАновлення регулятивного присічного строку Аля прийняття спаАщини на кшталт подібного відновлення позовної Аавності. ЄАина відмінність між змістом правового інструментарію, який застосовується, полягає у відсутності позитивної мотивації Аля віАновлення пропущеного присічного строку. Вважаємо це недоліком закону, аАже отримання майнового права на спалкове майно без вчинення своєчасно без поважних причин встановлених у правовому акті Аій щодо реалізації секундарного права фактично нівелює правове призначення присічного строку.

Більш серйозні питання виникають при оцінці правила ч. 3 ст. 1272, яке передбачає судове подовження тривалості пропущеного з поважних причин присічного строку Аля прийняття спаАщини. Бачимо, що вказаний механізм темпорального регулювання законодавець віАніс Ао спо- 
собів захисту порушеного права, аАже Аля його реалізації обрана позовна форма пред'явлення Аомагання [10, с. 292]. Такий підхіА, на наше переконання, $є$ не зовсім правильним. Згадаймо, що охоронне правовіАношення (а отже, і його елемент - право на позов) виникає після порушення регулятивного суб'єктивного права особи. Отже, за логікою законодавця, упродовж перебігу присічного строку Аля прийняття спаАщини регумятивне право спаАкоємця перебувало у не порушеному стані, а після спливу цього періоду воно отримало порушення.

Вказана позиція, очевидно, піАлягає серйозному корегуванню. По-перше, і головне, нереалізація самим носієм суб'єктивного права упродовж тривалості преклюзивного строку не породжує права на позов. Це випливає із самої юридичної природи секундарних прав [11, с. 8]. По-друге, важко, а часом просто неможливо встановити, хто $€$ зобов'язаною особою щодо позовного Аомагання спадкодавця, який пропустив строк Аля прийняття спаАщини, аАже причинами пропуску строку, скажімо, можуть бути події. НаприклаА, спаАкоємець проживав у іншій місцевості та не знав і не міг знати про смерть спаАкодавця, чи взагалі спадкоємець Аізнався про те, що він є таким, із серйозним запізненням. Отже, як бачимо, навіть за наявності поважних причин пропуску цього періоду, якщо і можна вважати право на прийняття спаАщини порушеним (хоча сама по собі категоричність подібного тверАження є суперечливою), все ж у значній кількості випадків не можна говорити про виникнення охоронно-правового віАношення, оскільки обов'язковим елементом останнього є охоронна вимога, алресована порушнику суб'єктивного права, а ця складова частина відсутня.

ВіАповідно Ао ч. 3 ст. 1272 ЦКУ, якщо строк пропущено з поважної причини, суд може визначити позивачу Аодатковий період, Аостатній А^я подання ним заяви про прийняття спаАщини. Власне, такий спосіб темпорального регулювання цивільних відносин є унікальним, що викликає серйозні сумніви у його Аоцільності [12, с. 72], аАже Аосить широко використовується та виправАало себе віАновлення пропущеного строку. Крім того, з огляду на викладене вище, за наявності описаних обставин застосування наведеного способу захисту порушеного права особи, котра пропустила строк Аля прийняття спаАщини, має відбуватися не у позовній формі [13, с. 310]. Якщо вже законодавець обрав Аля подовження пропущеного строку судовий механізм, то сліА використовувати окреме провадження - виА непозовного цивільного суАочинства, в поряАКу якого розгляАаються цивільні справи про підтверАження наявності або відсутності юридичних фактів, що мають значення Аля охорони прав та інтересів особи чи створення умов зАійснення нею особистих немайнових чи майнових прав або підтвердження наявності чи віАсутності неоспорюваних прав (ч. 1 ст. 234 ЦПК) [14, с. 144].

Ще одна практична ситуація - коли зазвичай віАбувається підміна темпоральних, регулятивних та охоронних вимірів. Мусимо критично оцінити тверАження про присічний характер строку преА'явлення вимоги про звільнення майна з-піА арешту. Послідовно керуючись означеними вище принципами, можемо стверджувати, що це повноваження, безумовно, належить до способів захисту права власності [15, с. 69]. Сам же захист існує ^ише тоді, коли є об'єкт захисту - порушене матеріальне право. Останнє, у свою чергу, відбувається внаслідок певних Аій (арешту) й у певний момент, віА якого за загальним правилом починається існування матеріального права на судовий захист, яке має властивість задавнюватися.

Наведемо приклаА із судової практики, котрий проіююструє коментовану нами тезу про підміну правового забезпечення перебігу Аавнісних строків, на те, що використовується Аля строків заійснення регулятивного права і навпаки. Так, Вищий господарський суА України у своїй постанові визначив встановлений місячний строк Аля звернення Ао суду із позовом про визнання неАійсним угод за результатами проведення аукціону чи конкурсу відповіАно Ао ч. 2 ст. 20 Закону України "Про приватизацію невеликих державних піАприємств (малу приватизацію)" присічним. СуА віАмовив у застосуванні правила про відновлення позовної давності [16], та, якби піА час постановлення рішення він проаналізував реальну сутність віАносин, то, безумовно, обрав би зовсім інший, правильний підхіА. Справа в тому, що шляхом звернення до суду позивач реалізовував свої охоронне право, яке виникло внаслідок порушення його регулятивного повноваження на належну участь у приватизаційному аукціоні чи конкурсі. Строком охоронно-правової вимоги $€$ позовна Аавність, котра у разі поважності пропуску піАлягає обов'язковому відновленню (ч. 5 ст. 267 ЦКУ).

Висновки 3 дослідження та перспективи подальших розвідок у цьому напрямі. Отже, у літературі та на практиці віАсутній однозначний піАхіА Ао того, які саме цивільні строки сліА віАносити Ао регулятивних чи охоронних, і цьому Аійсно 
сприяє непослідовність нашого законодавства. Між вказаними цивільними строками є відмінності, котрі не Аозволяють їх ототожнити. На нашу Аумку, головним критерієм віАмінностей між суспільними відносинами, що регулюються правовим інструментарієм позовної давності, та тих, які підпадають піА сферу Аії норм, котрі встанов- ^юють прек^юзивні строки, є те, що преАметом Аії кожного з них є різне за своєю юридичною природою суб'єктивне матеріальне право: класичний присічний строк обмежує період реалізації регулятивного права, тоді як зі збігом позовної Аавності погашається охоронне право (позовне Аомагання).

\section{NITEPATYPA:}

1. Васьковский Е.В. Учебник гражданского права. Москва : Издание Бр. Башмаковых, 1917. 429 с.

2. Ц Цивільний кодекс України: науково-практичний коментар / за ред. О.В. Дзери, Н.С. Кузнєцової, В.В. Луця. Київ : Юрінком Інтер, 2004. 928 c.

3. Гуйван П.Д. Теоретичні питання строків у приватному праві : монографія. Харків : Право, 2014. 632 с.

4. Луць В.В. Строки в цивільних правовідносинах: Конспекти лекцій з спецкурсу. Львів : Вид-во ЛДУ, 1992.

5. Советское гражданское право : учебник / ред. Генкин Д.М. Москва : Госюриздат, 1950. Т. 1. 495 с.

6. Крашенинников Е.А. Понятие и предмет исковой давности. Ярославль, 1997. 86 с.

7. Крашенинников Е.А. К учению об исковой давности. Материально-правовые и процессуальные средства охраны и защиты прав и интересов хозяйствующих субъектов. Калинин, 1987. С. 53-59.

8. Вошатко А.В. Начало течения давностного срока по притязанию на выплату страхового возмещения. Проблемы защиты субъективных гражданских прав : сборник научных трудов. Ярославль, 2001. С. 39-45.

9. Лебедева К.Ю. Классификация сроков в гражданском праве. Журнал российского права. 2001. № 9. С. $75-82$.

10. Городилова О.О. Строки реалізації права на прийняття спадщини та спадкова трансмісія як особливий випадок набуття спадщини. Вісник Харківського наи. університету внутрішніх справ. 2008. № 43. С. 290-295.

11. Thon, A. Rechtsnorm und subjektives Recht. Weimar, 1887. $282 \mathrm{~s}$.

12. Сасина Л.А. Спорные вопросы сроков в наследственном праве. Вестник Московского университета. 1986. № 6. С. 70-75.

13. Рябоконь Е.А. Предоставление наследнику дополнительного срока для принятия наследства (на основе материалов судебной практики). Альманах цивилистики. Вып. 2. 2009. С. 306-336.

14. Рябоконь С.О. Спадкове правовідношення у цивільному праві. Київ : Віпол, 2002. 266 с.

15. Тыртычный С.А. Защита имущественных прав собственника по современному российскому законодательству : дис. ... канд. юрид. наук. Москва, 2004. 169 с.

16. Постанова Вищого Господарського суду України. Справа № 20-12/077 19 січня 2006 p. URL: http://arbitr.gov.ua/docs/ $28 \_1162075 . \mathrm{html}$.

\section{Гуйван Петро Амитрович}

ПРАВОВЕ СПІВВІАНОШЕННЯ СТРОКІВ ЗАІЙСНЕННЯ РЕГУАЯТИВНОГО Й ОХОРОННОГО ЦИВІЛЬНОГО ПРАВА

Наукова стаття присвячена порівнянню строків зАійснення регулятивного цивільного права та строків реалізації права на захист у разі правопорушення. Попри зовнішню схожість вказаних темпоральних характеристик, у роботі відзначається їхня різна сутність і призначення. Особлива увага надається АосліАженню таких матеріально-правових строків: присічних регулятивних і давнісних (позовна Аавність). Річ у тім, що у доктрині часто з їхнім спливом пов'язується припинення суб'єктивного права та можливості його судового захисту. Ми наголошуємо на тому, що це не так. Не можна погодитися із твердженням, ніби закінчення присічного строку одночасно погашає притаманну захисну властивість права. Погасити можна лише те право, що вже виникло, тобто повноваження, яке існує. Якщо ж протягом присічного строку матеріальне право, зАійснення якого полягає у вчиненні певних активних дій, не було реалізоване, немає підстав говорити про його порушення. Після закінчення періоду Аії правовстановлюючого повноваження особи, що не було реалізоване самим носієм, право на захист не припиняється, воно просто не виникає. ПіАкреслюється, що правильне розуміння характеру правовіАношення, котре перебуває в певному стані, Аозволить уникнути неправильної оцінки моменту, коли в зобов'язанні фактично віАбулося правопорушення, а це надасть можливість реально захистити своє матеріальне право. Наведені конкретні ситуації, коли правова природа відносин не є очевидною, висловлена обґрунтована критика окремих піАходів, коли нечіткість і суперечливість окремих норм вітчизняного законодавства призводить до суперечливого правозастосування. Зокрема, вказується, що страховий випадок призводить до виникнення не охоронного, а регулятивного права, якому кореспондує регулятивний обов'язок зАійснити страхову виплату, і лише у разі невиконання вказаного обов'язку у встановлений договором чи правилами страхування строк віАбудеться порушення вказаного суб'єктивного права та з'явиться можливість юридичного захисту.

Ключові слова: присічний строк, позовна давність, правовідношення.

\section{Guyvan Petro}

\section{LEGAL RATIO OF TERMS OF IMPLEMENTATION OF REGULATORY AND PROTECTIVE CIVIL LAW}

This scientific article is devoted to the study of the comparison of the drains of the implementation of regulatory civil law and the timing of the right to protection in case of offense. Despite the external similarity of these temporal characteristics, the work notes their different nature and purpose. Particular attention is paid to the study of the 
following substantive legal terms: regulatory and statutory deadlines (statute of limitations). The fact is that in doctrine, their emergence is often associated with the termination of subjective law and the possibility of its judicial protection. We emphasize that this is not the case. It is impossible to agree with the statement that the expiration of the cut-off period simultaneously extinguishes the inherent protective property of the right. Only the right that has already arisen, ie the existing authority, can be extinguished. If during the cut-off period the substantive law, the implementation of which consists in the commission of certain active actions, has not been implemented, there is no reason to speak of its violation. After the expiration of the period of validity of the right of establishment of a person who has not been exercised by the holder, the right to protection does not cease, it simply does not arise. It is emphasized that a correct understanding of the nature of the legal relationship, which is in a certain state, will avoid misjudging the moment when the obligation actually occurred in the offense. And this will provide an opportunity to really protect their substantive rights. There are specific situations when the legal nature of the relationship is not obvious, there is a reasonable criticism of certain approaches, when the vagueness and inconsistency of certain rules of domestic law leads to contradictory law enforcement. In particular, it is stated that the insured event leads to the emergence of not a protection, but a regulatory right, which corresponds to the regulatory obligation to make an insurance payment. And only in case of non-fulfillment of the specified obligation in the term established by the contract or rules of insurance there will be a violation of the specified subjective right and there is a possibility of legal protection.

Key words: cut-off period, statute of limitations, legal relationship. 